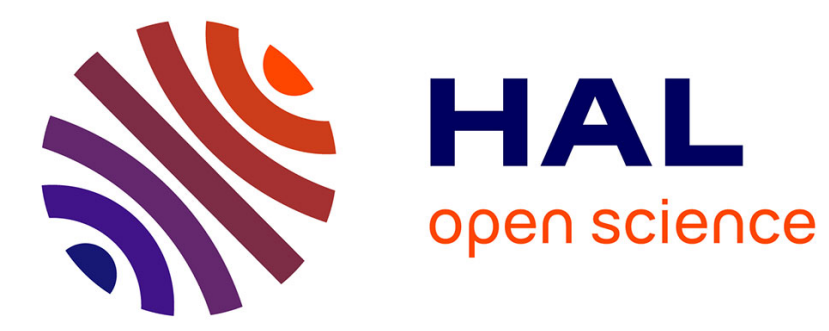

\title{
Intestinal transfer of growth hormone into the circulatory system of the rainbow trout,Salmo gairdneri: Interference by granule cells
}

Pierre-Yves Le Bail, Marie-France Sire, Jean-Marie Vernier

\section{To cite this version:}

Pierre-Yves Le Bail, Marie-France Sire, Jean-Marie Vernier. Intestinal transfer of growth hormone into the circulatory system of the rainbow trout,Salmo gairdneri: Interference by granule cells. Journal of Experimental Zoology, 1989, 251 (1), pp.101-107. 10.1002/jez.1402510112 · hal-02728126

\section{HAL Id: hal-02728126 \\ https: / hal.inrae.fr/hal-02728126}

Submitted on 2 Jun 2020

HAL is a multi-disciplinary open access archive for the deposit and dissemination of scientific research documents, whether they are published or not. The documents may come from teaching and research institutions in France or abroad, or from public or private research centers.
L'archive ouverte pluridisciplinaire HAL, est destinée au dépôt et à la diffusion de documents scientifiques de niveau recherche, publiés ou non, émanant des établissements d'enseignement et de recherche français ou étrangers, des laboratoires publics ou privés. 


\title{
RAPID COMMUNICATION
}

\section{Intestinal Transfer of Growth Hormone Into the Circulatory System of the Rainbow Trout, Salmo gairdneri: Interference by Granule Cells}

\author{
PIERRE-YVES LE BAIL, MARIE-FRANCE SIRE, \\ AND JEAN-MARIE VERNIER \\ Laboratoire de Physiologie des Poissons, INRA, Campus de Beaulieu, 35042 \\ Rennes (P.-Y.L.B.) and Laboratoire de Cytophysiologie de la Nutrition des \\ Poissons, URA D 646 CNRS, Université Paris-Sud, 91405 Orsay (M.-F.S., \\ J.-M.V.), France
}

\begin{abstract}
To test if growth hormone, well known for its strong effect on fish growth, could be incorporated into the diet, bovine growth hormone (bGH) was introduced into the lumen of the digestive tract of trout yearling (Salmo gairdneri). Radioimmunoassay (RIA) and radioreceptorassay (RRA) were used to assess plasma concentration of bGH. In our experimental conditions, the concentration of bGH peaks after 1 hour, in treated fish only, attesting to the intestinal hormone transfer (coefficient of absorption is about $0.2 \%$ ). Immunocytochemistry is used to follow the hormone transfer process. Most bGH molecules absorbed by enterocytes of the distal segment are found in the vacuoles (phagolysosomes) of the apical hyaloplasm. A small part escapes the intracellular degradation and is found in the intercellular space and in the interstitial space of the lamina propria. At this level, the granule cells trapped the antigenic hormone, as did immune cells.

The results of this study indicate that oral administration of GH can be potentially used in fish culture.
\end{abstract}

It has been known for a number of years that bovine growth hormone (bGH) can be used as growth promoting agent in teleost fish (see review by Donaldson et al., '79). Its administration leads to an increase in the growth rate (two- or threefold), a reduction in adipose tissue, and a better transformation index. The treatment methods (injection, implant, dip), however include a number of inherent difficulties (intensive manipulation), and the likely side effects resulting from scale removal and frequent handling of the fish can create sites for bacterial infections. Two strategies are currently envisioned: one involves transferring growth hormone genes (Chourrout et al., '86; Dunham et al., ' 87 ); the other is derived from new data on protein absorption, especially in salmonids, consistent with the possibility of the incorporation of the hormone into fish diet, a suitable treatment in fish farming.

Proteins ingested by teleost fish can be transferred to the circulatory system, intact or partially hydrolyzed (Georgopoulou et al., '86; McLean and Ash, '86, '87; Suzuki et al., '88). Studies in rainbow trout have shown that transfer of ingested proteins into the plasma occurs in the posterior gut via enterocytes, which are structur- ally differentiated for absorbing proteins and carrying out intracellular digestion (Georgopoulou et al., '88). Numerous macrophages and lymphoid cells are infiltrated between the epithelial cells in teleost fish (Zapata, '79; Davina et al., '80; Lamers, '85). A portion of the antigen molecules transferred enters into contact with macrophages, which can ingest them (Noaillac-Depeyre and Gas, '76; Rombout et al., '85; Georgopoulou and Vernier, ' 86 ). The analogy between the absorbing enterocyte in the posterior intestine of teleost fish and the $M$ cell of the mammalian intestinal epithelium is extended by the demonstration of the existence of secretory immunoglobulinforming cells in the same intestinal segment (Georgopoulou and Vernier, '86). Protein ingestion would thus be capable of triggering a local immune response.

A general feature of the digestive tract of salmonids is the presence of a continuous collagen

\footnotetext{
Received September 29, 1988; revision accepted March 7, 1989

Address reprint requests to Professor J.M. Vernier, Laboratoire de Cytophysiologie de la Nutrition des Poissons, URA D 646 CNRS, Université Paris-Sud, 91405 Orsay Cedex, France.

This work was presented in part at the "Colloque franco-belge de microscopie électronique," Lille, France, May 17-20, 1988.
} 
layer in the lamina propria, called the stratum compactum, which is associated with eosinophilic granule cells. These two structural components are absent in young fish and appear in the course of development (Kimura and Kudo, '75; Ezeasor, '86). A continuous layer of granule cells, the stratum granulosum, is present in 1-year-old fish (Woodward and Bergeron, '84). The stratum compactum and granular cells are believed to form a composite defense system, mechanical and humoral, which develops in response to demands by the environment (Ezeasor and Stokoe, '80).

We have verified that bGH passes through the intestinal barrier of trout into the circulatory system as well as the possible involvement in this transfer of granule cells which colonize the lamina propria.

\section{MATERIAL AND METHODS}

Rainbow trouts, Salmo gairdneri, (26 weeks old) weighing $30-45 \mathrm{~g}$ and raised in the laboratory in running water with constant flow-rate and temperature $\left(12 \pm 1^{\circ} \mathrm{C}\right)$ were fasted for 3 days before beginning experiments.

Anesthetized animals $(0.3 \mathrm{ml}$ of phenoxy-2ethanol/liter of water) received $500 \mu \mathrm{l}$ of $0.7 \%$ $\mathrm{NaCl}$ containing $1 \mathrm{mg}$ of bGH (B1 from the National Hormone and Pituitary Program, NHPP; MW: 22,000) into the posterior intestinal lumen, by the anal way, with the aid of a catheter. Controls received $500 \mu \mathrm{l}$ of $0.7 \% \mathrm{NaCl}$ alone.

Blood and tissue samples were obtained $30 \mathrm{~min}$, $1,3,4,7$, and $14 \mathrm{hr}$ after bGH administration. For each time, three animals were used.

\section{Plasma assays of bGH}

Heparinized blood samples were taken from the caudal vasculature. After centrifugation, plasma were stored at $-20^{\circ} \mathrm{C}$ until GH measurement by assays.

Reagents and bGH radioimmunoassay (RIA) procedure came from NHPP. Sensitivity was 0.2 $\mathrm{ng} / \mathrm{ml}$, and cross reactivity of salmonid $\mathrm{GH}$ was less than 1\% (Le Bail et al., unpublished data).

bGH activity was tested using a mammalian receptor assay according to the technique of Gerasimo et al., ('79). bGH (USDA bGH I1) for standards and iodination came from NHPP. Sensitivity was $1 \mathrm{ng} / \mathrm{ml}$ (Le Bail et al., '89), and crossreactivity of salmonid $\mathrm{GH}$ was about $10 \%$ (Nicoll et al., '87).

The coefficient of absorption of bGH was determined by applying the principle of occupation (Shimmins et al., '69). To determine the kinetics of disappearance of bGH into the plasma, the dorsal aorta of two trouts was catheterized according to the technique of Zohar ('80). bGH ( $3 \mu \mathrm{g} / 100 \mu \mathrm{l}$ of $\mathrm{NaCl} 0.7 \%$ ) was injected into the dorsal aorta, and $50 \mu \mathrm{l}$ of blood was sampled every $30 \mathrm{~min}$ during $4 \mathrm{hr}$. Plasma was stored at $-20^{\circ} \mathrm{C}$ before bGH radioimmunoassay. For calculations, total plasma volume was taken as $4 \%$ of animal body weight (Zohar, '82).

\section{Immunoelectron microscopy techniques}

Fragments of posterior intestine were fixed for $2 \mathrm{hr}$ at ambient temperature with $0.5 \%$ glutaraldehyde in $0.1 \mathrm{M}$ phosphate buffer (PBS), $\mathrm{pH} 7.4$, then rinsed in the same buffer and embedded in Epikote 812. Ultrathin sections were deposited on copper grids coated with formvar. One drop of $1 \%$ of ovalbumin in PBS was deposited on each grid for $5 \mathrm{~min}$. The sections were incubated $2 \mathrm{hr}$ at ambient temperature with the anti-bGH (NHPP, diluted $1 / 500$ ) and then rinsed with PBS. The protein A/colloidal gold (Sigma) complex was then deposited on each grid for $1 \mathrm{hr}$ at ambient temperature. After rinsing with PBS and distilled water, the sections were counterstained with uranyl acetate for $15 \mathrm{~min}$, then examined by electron microscopy.

\section{RESULTS}

The assay results (Fig. 1A,B) show that a fraction of bGH added to the posterior intestinal lumen reached the circulatory system. Transfer was rapid, since the plasma peak was situated between 30 and $180 \mathrm{~min}$. Plasma load remained high until more than $7 \mathrm{hr}$ after administration. Clearance appeared to be complete after $14 \mathrm{hr}$. The half-life of bGH, obtained from assay results (Fig. 1C) is about $44 \mathrm{~min}$. The intubated bGH passed through the intestinal epithelium and entered into the general circulation is about $0.2 \%$.

Immunocytochemistry was used to follow the bGH absorption process by the intestinal epithelium. The hormone could be visualized in the vacuoles of the apical hyaloplasm (Fig. 4), which were numerous at all stages of the observations (Fig. 2); visualization was difficult in the intercellular spaces between enterocytes (Fig. 4). The hormone was also present (Fig. 5) in vacuoles of various sizes in numerous macrophages infiltrated in this space (Figs. 2, 3). At the base of the epithelium, bGH crossed the basal membrane and could be seen disseminated in the interstitial space of the lamina propria. In all animals, the granule cells of the lamina propria, dispersed or 

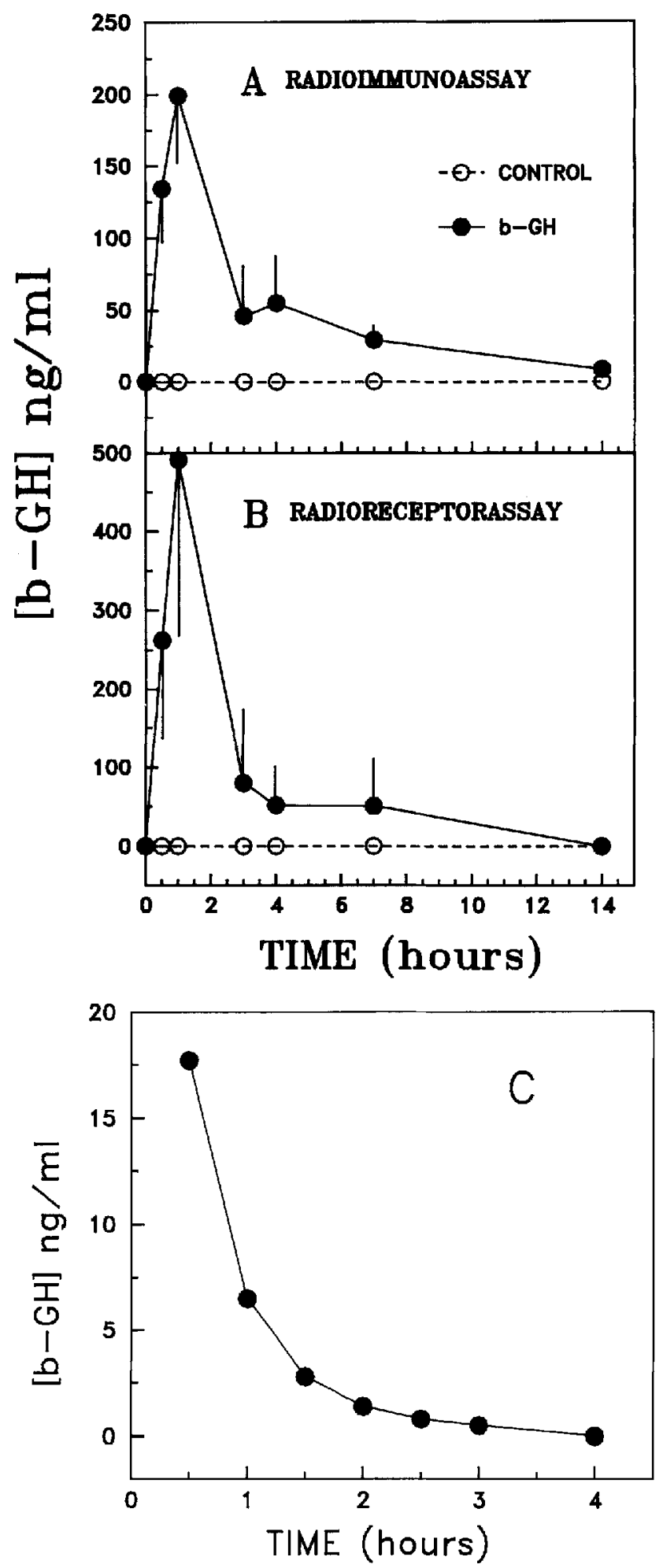

Fig. 1. A,B: Kinetics of appearance of bGH in the plasma after anal administration of bGH (1 mg/500 $\mu \mathrm{l} \mathrm{NaCl} 0.7 \%)$. Each sample corresponds to three animals. Vertical bars: standard error of the mean. A: RIA assay. B: RRA Assay. C: Kinetics of disappearance of $\mathrm{bGH}$ in trout plasma after intravenous administration of $\mathrm{bGH}(3 \mu \mathrm{g} / 100 \mu \mathrm{l} \mathrm{NaCl} 0.7 \%)$. clustered immediately under the epithelium or in contact with the stratum compactum (Fig. 3), exhibited a spectacular and specific labeling of their grains (Fig. 6). This label was absent in the granule cells of control animals (Fig. 7).

\section{DISCUSSION}

Both zootechnical and ontogenic considerations were used for the choice of the animals, juveniles 26 weeks posthatching, bodyweight 30 to $45 \mathrm{~g}$. On the one hand, it was economically advantageous to modify the growth curve early in the course of development. It has been found that fish undergoing growth gains early in development remain larger than their peers (Donaldson et al., '79). Agellon et al. ('88b) showed the efficacy of a recombinant growth hormone by the dip method in rainbow trout fries $(1.32 \pm 0.6 \mathrm{~g})$ and by the intraperitoneal injection in yearling $(77 \pm 13 \mathrm{~g})$ of the same species. Kawauchi et al. ('86) also obtained positive results with the latter method in $10 \mathrm{~g}$ salmon yearlings. In addition, administration at an early stage reduces the quantities of hormone required and consequently the cost of the experiments. On the other hand, results published by Bergeron and Woodward ('82) on the ontogenesis of the stratum granulosum of the rainbow trout intestine showed that after this stage, all the animals possess granule cells in the lamina propria. Although ontogenesis exhibits considerable interindividual variability, its steps are always the same. The cells are at first dispersed, subsequently forming agglomerates of four to five cells. Finally, they form a practically continuous cell layer, the stratum granulosum, in contact with the stratum compactum. At 12$13^{\circ} \mathrm{C}$, this development occurs between weeks 24 and 34 . At this time, the stratum granulosum is in place in all animals. We thus chose animals that could correspond to either of these steps and thus be able to test the hypothesis of the installation of a local immune system (Ezeasor and Stokoe, '80; Ezeasor, '86).

The results of plasma assays show the bGH transfer actually occurs. Up to more than $7 \mathrm{hr}$ after administration, concentrations of bGH obtained by RIA can be considered as very high if they are compared to the level of endogenous GH ( $2 \mathrm{ng} / \mathrm{ml}$ : unpublished results of several hundred assays in trout of different sizes) and high when taking into account data on coho salmon yearlings in which the mean plasma GH concentrations are 32 and $41 \mathrm{ng} / \mathrm{ml}$, respectively, in animals raised in sea water or fresh water, weighing 

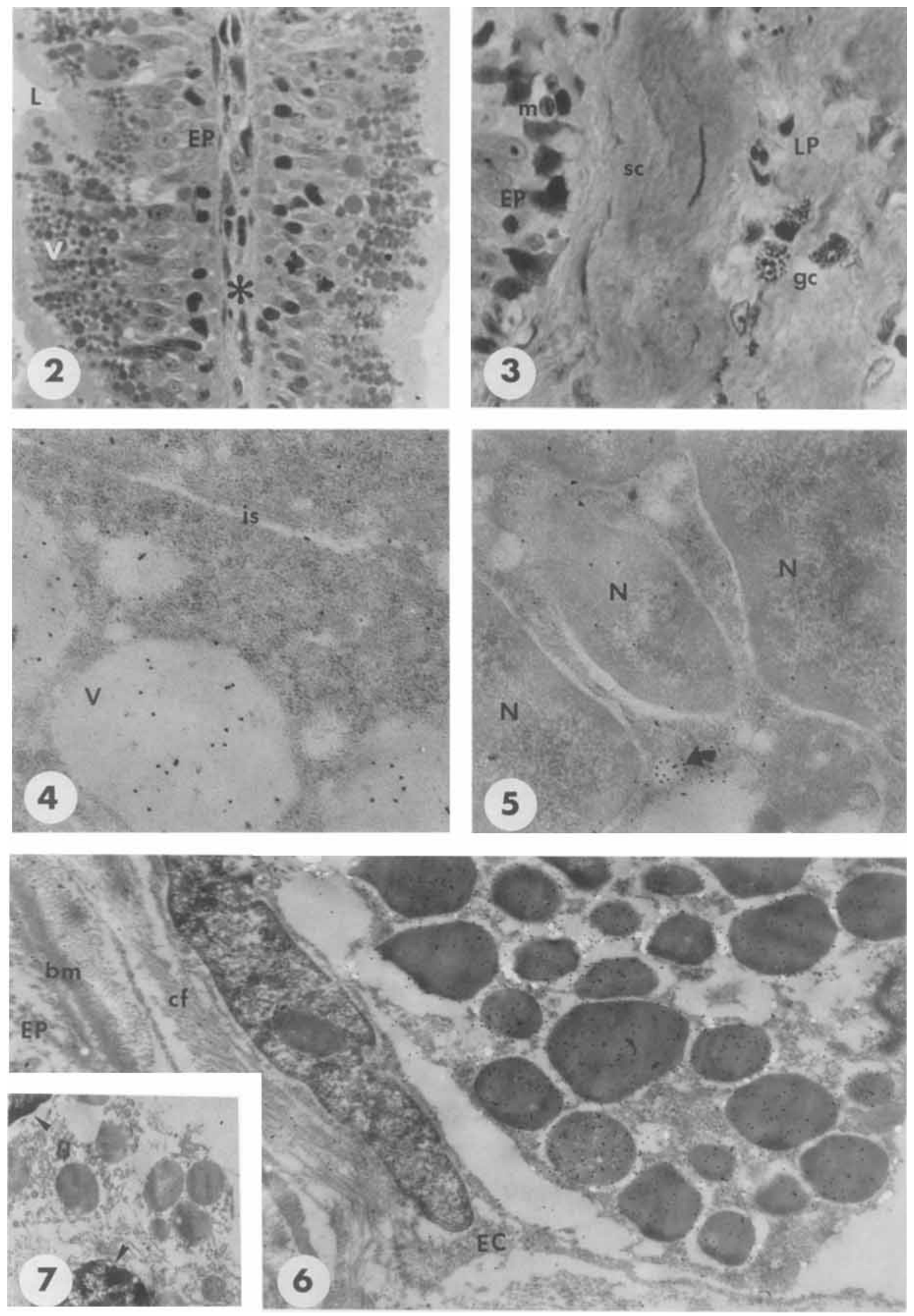

Figures 2-7 
78 and $87 \mathrm{~g}$ (Bolton et al., '87). The higher levels of bGH obtained with RRA than with RIA are the usual ones found (Nicoll, '75). During bGH transfer, the binding sites with receptors are preserved, consistent with the hormone's remaining potentially active. Moore et al. ('86) showed that rectal administration of bGH enhances growth of hypophysectomized rats. The anal introduction of the hormone, in direct contact with cells that can absorb it, results in its rapid transfer. A pronounced plasma peak was observed as soon as the first hour. By analogy with results with horseradish peroxidase (HRP) (Georgopoulou et al., '86, '88; Sire et al., '88), it is possible that the oral administration of bGH leads to a slower and more prolonged transfer of $\mathrm{bGH}$, with a less pronounced plasma peak. The transport of orally ingested salmon GtH through the digestive epithelium in goldfish is reflected by the ensuing high levels of salmon $\mathrm{GtH}$ in the plasma, the increases reaching maximal levels at 6 to $12 \mathrm{hr}$ (Suzuki et al., '88).

The transepithelial passage of bGH occurs at the level of the absorbing enterocytes. Most bGH molecules that penetrate the cells are degraded: the vacuoles of the apical hyaloplasm where the hormone can be localized are phagolysosomes

Figs. 2-6. Sections of the posterior intestine of a $32 \mathrm{~g}$ troutlet, $1 \mathrm{hr}$ after administering bGH. Figs. 2 and 3 . Semithin sections stained with toluidine blue.

Fig. 2. Section at the level of a fold. Above the lamina propria $(*)$, tall and thin enterocytes (EP) with a highly vacuolized hyaloplasm (V). The nuclei are in basal position. $\mathrm{L}$, lumen $(\times 624)$.

Fig. 3. At the base of the epithelium (EP), note the presence of numerous infiltrated lymphoid cells, particularly macrophages (m). Granule cells (gc), characteristic element of the digestive tract of salmonids, are present under the stratum compactum (sc) already well differentiated. LP, lamina propria $(\times 770)$.

Figs. 4-7. Ultrathin sections. Protein A-colloidal gold. Fig. 4. Gold grains showing the presence of bGH are seen in the vacuoles (V) of the apical hyaloplasm of the epithelial cells and in the intercellular space (is) $(\times 30,000)$.

Fig. 5. Fragment of the macrophage infiltrated between epithelial cells above the basal membrane, before uptake of $\mathrm{bGH}$, sequestered in the vesicles (arrow). $\mathrm{N}$, lobes of nucleus $(\times 18,000)$.

Fig. 6. Granule cells situated just below the basal membrane (bm) having taken up bGH. This cell is surrounded by cytoplasmic projections of a fibroblast-type "enveloping cell" (EC). EP, epithelial cell; cf, collagen fibers $(\times 16,000)$.

Fig. 7. Control animal. Two granule cells lacking specific label. Arrowheads; nuclei $(\times 8,000)$.
(Georgopoulou et al., '85, '86). Molecules escaping degradation follow the same path as that described for HRP (Georgopoulou et al., ' 88 ; Sire et al., '88), i.e., intercellular space separating the enterocytes, interstitial space of the lamina propria, capillaries whose ultrastructure is the same as that of mammalian lymphatic capillaries. The posterior intestine of the trout is thus structurally and functionally comparable to the ileum of suckling rodents. In these animals, milk proteins are absorbed and degraded by the enterocytes (Wilson et al., '87). Furthermore protein fragments resulting from intracellular degradation, such as epidermal growth factor (Gonella et al., '87), as well as intact peptides, such as nerve growth factor (Siminoski et al., '86), may reach the lamina propria. The immunoelectron microscopy results of this study have for the first time shown the interference of granule cells of the lamina propria with the transepithelial transport of a protein. Regardless of the animal and the developmental stage of these cells (dispersed, clustered, arranged in a continuous layer), the administration of bGH results in a slight labeling of their hyaloplasm and very intense labeling of the granules; label is absent in the cells of control animals. The role of the stratum granulosum of the lamina propria has until the present remained unknown. Bergeron and Woodward ('82) showed that granule cells did not participate in the differentiation of the stratum compactum. Until now, no finding has supported the second hypothesis often advanced of their belonging to a local immune system (Ezeasor and Stokoe, '80; Ezeasor, '86) composed of mobile cells transported by the circulatory system (Bergeron, '82; Bergeron and Woodward, '83). The present results show that proteins, bGH in this case, are trapped by granule cells, which thus behave as immune cells. It is to be remembered that the transepithelial passage of a protein triggers an immune reaction in the posterior intestine (Georgopoulou and Vernier, '86); in addition, granule cells are observed in salmonid gills, skin, and nostrils (Roberts et al., '73).

The induction of growth in the rainbow trout by the oral administration of bGH should be performed in young subjects before the definitive installation of the stratum granulosum (week 34 at $12-13^{\circ} \mathrm{C}$ ). As a result of biotechnology, the possibility of using salmon GH (Sekine et al., '85; Nicoll et al., ' 87 ) or even better that of rainbow trout (Agellon and Chen, '86; Agellon et al., '88 a,b) should lead to improved efficacy of oral administration of the hormone, avoiding interference by granule cells and enabling the treatment 
to be prolonged beyond the installation of the stratum granulosum, or even to be applied at a later developmental stage.

\section{ACKNOWLEDGMENTS}

We thank Dr. T. Magot for help with the determination of the coefficient of absorption. This study was supported by research grant from GCS/ BBA (IFREMER, INRA, MRES). bGH and antibGH were gifts from National Hormone and Pituitary Program.

\section{LITERATURE CITED}

Agellon, L.B., and T.T. Chen (1986) Rainbow trout growth hormone: Molecular cloning of cDNA and expression in Escherichia coli. DNA, 5:463-471.

Agellon, L.B., S.L. Davies, T.T. Chen, and D.A. Powers (1988a) Structure of a fish (rainbow trout) growth hormone gene and its evolutionary implications. Proc. Natl. Acad. Sci. U.S.A. 85:5136-5140.

Agellon, L.B., C.J. Emery, J.M. Johns, S.L. Davies, A.D. Dingle, and T.T. Chen (1988b) Promotion of rapid growth of rainbow trout (Salmo gairdneri) by a recombinant fish growth hormone. Can. J. Fish. Aquat. Sci., 45: 146-151.

Bergeron, T. (1982) Ultrastructural and Histochemical Assessment of the Granule Cells of the Rainbow Trout (Salmo gairdneri) Small Intestine. M. Sc. Thesis. University of Guelph, Guelph, Ont. (USA).

Bergeron, T., and B. Woodward (1982) The development of the stratum granulosum of the small intestine of the rainbow trout (Salmo gairdneri). Can. J. Zool., 60: 1513-1516.

Bergeron, T., and B. Woodward (1983) Ultrastructure of the granule cells in the small intestine of the rainbow trout (Salmo gairdneri) before and after stratum granulosum formation. Can. J. Zool., 61:133-138.

Bolton, J.P., G. Young, R.S. Nishioka, T. Hirano, and H.A. Bern (1987) Plasma growth hormone levels in normal and stunted yearling coho salmon, Oncorhynchus kisutch. J. Exp. Zool., 242:379-382.

Chourrout, D., R. Guyomard, and L.M. Houdebine (1986) High efficiency gene transfer in rainbow trout (Salmo gairdneri Rich.) by microinjection into egg cytoplasm. Aquaculture 51:143-150.

Davina, J.H.M., G.T. Rijkers, J.H.W.M. Rombout, L.P.M. Timmermans, and W.B. Van Muiswinkel (1980) Lymphoid and non-lymphoid cells in the intestine of cyprinid fish. In: Development and Differentiation of Vertebrate Lymphocytes. J.D. Horton, ed. Elsevier/North Holland Biomedical Press, Amsterdam, pp. 129-140.

Donaldson, E.M., U.H.M. Fagerlund, D.A. Higgs, and J.R. McBride (1979) Hormonal enhancement of growth. In: Fish Physiology. W.S. Hoar, D.J. Randall and J.R. Brett, eds. Academic Press, New York, Vol. VIII, pp. 455-597.

Dunham, R.A., J. Eash, J. Askins, and T.M. Townes (1987) Transfer of the metallothionein-human growth hormone fusion gene into channel catfish. Trans. Am. Fish. Soc., 116:87-91.

Ezeasor, D.N. (1986) The structure and functional significance of stratum compactum in the gut of the rainbow trout (Salmo gairdneri, Rich.). Z. Mikrosk. Anat. Forsch., 100:536-544.
Ezeasor, D.N., and W.M. Stokoe (1980) A cytochemical, light and electron microscopic study of the eosinophilic granule cells in the gut of the rainbow trout, Salmo gairdneri Richardson. J. Fish Biol., 17:619-634.

Georgopoulou, U., and J.M. Vernier (1986) Local immunological response in the posterior intestinal segment of the rainbow trout after oral administration of macromolecules. Dev. Comp. Immunol., 10:529-537.

Georgopoulou, U., M.F. Sire, and J.M. Vernier (1985) Macromolecular absorption of proteins by epithelial cells of the posterior intestinal segment and their intracellular digestion in the rainbow trout. Ultrastructural and biochemical study. Biol. Cell, 53:269-282.

Georgopoulou, U., M.F. Sire, and J.M. Vernier (1986) Immunological demonstration of intestinal absorption and digestion of macromolecules in the trout (Salmo gairdneri). Cell Tissue Res., 245:387-395).

Georgopoulou, U., K. Dabrowski, M.F. Sire, and J.M. Vernier (1988) Absorption of intact proteins by the intestinal epithelium of trout, Salmo gairdneri. A luminescence enzyme immunoassay and cytochemical study. Cell Tissue Res., $251: 145-152$.

Gerasimo, P., J. Djiane, and P.A. Kelly (1979) Titration of total binding site for growth hormone in rabbit liver. Quantitative modifications of these sites during pregnancy. Mol. Cell. Endocrinol., 13:11-23.

Gonella, P.A., K. Siminoski, R.A. Murphy, and M.R. Neutra (1987). Transepithelial transport of epidermal growth factor by absorptive cells of the suckling rat ileum. J. Clin. Invest., 80:22-32.

Kawauchi, H., S. Moriyama, A. Yasuda, K. Yamaguchi, K. Shirahata, J. Kubota, and T. Hirano (1986) Isolation and characterization of chum salmon growth hormone. Arch. Biochem. Biophys., 244:542-552.

Kimura, N., and S. Kudo (1975). Fine structure of the stratum granulosum of the pyloric caeca of the rainbow trout. Jpn. J. Ichthyol., 22:16-22.

Lamers, C.H.J. (1985) The Reaction of the Immune System of Fish to Vaccination. PhD Thesis. Wagenigen (Netherlands).

Le Bail, P.Y., G. Boulard, B. Barenton, and M. Zigmunt (1989) Purification of chinook salmon (Oncorhynchus tshawytscha) GH for receptor study. Fish Physiol. Biochem., (in press).

McLean, E., and R. Ash (1986) The time-course of appearance and net accumulation of horseradish peroxidase (HRP) presented orally to juvenile carp Cyprinus carpio (L.). Comp. Biochem. Physiol., [A], 84:687-690.

McLean, E., and R. Ash (1987) The time-course of appearance and net accumulation of horseradish peroxidase presented orally to rainbow trout Salmo gairdneri (Richardson). Comp. Biochem. Physiol. [A], 88:507-510.

Moore, J.A., S.A. Pletcher, and M.J. Ross (1986). Absorption enhancement of growth hormone from the gastrointestinal tract of rats. Int. J. Pharm., 34:35-43.

Nicoll, C.S. (1975) Radioimmunoassay and radioreceptor assay for prolactin and growth hormone: A critical appraisal. Am. Zool., 15:881-903.

Nicoll, C.S., S.S. Steiny, D.S. King, R.S. Nishioka, G.L. Mayer, N.L. Eberhard, J.D. Baxter, M.K. Yamanaka, J.A. Miller, J.J. Seilhamer, J.W. Schilling, and L.K. Johnson (1987) The primary structure of the coho salmon growth hormone and its cDNA. Gen. Comp. Endocrinol., 68:387399.

Noaillac-Depeyre, J., and N. Gas (1976) Electron microscopic 
study on gut epithelium of tench (Tinca tinca) with respect to its absorptive functions. Tissue Cell, 8:511-530.

Roberts, R.J., A. McQueen, U.M. Shearer, and H. Young (1973) The histopathology of salmon tagging. II. The chronic tagging lesion in returning adult fish. J. Fish Biol., 5:615-619.

Rombout, J.H.W.M., C.H.J. Lamers, M.H. Helfrich, A. Dekker, and J.J. Taverne-Thiele (1985) Uptake and transport of intact macromolecules in the intestinal epithelium of carp (Cyprinus carpio L.) and the possible immunological implications. Cell Tissue Res., 239:519-530.

Sekine, S., T. Mizukami, T. Nishi, Y. Kuwana, A. Saito, M. Sato, S. Itoh, and H. Kawauchi (1985) Cloning and expression of cDNA for salmon growth hormone in Escherichia coli. Proc. Natl. Acad. Sci. U.S.A., 82:4306-4310.

Shimmins, J., F.C. Gillespie, J.S. Orr, D.A. Smith, and W.D. Alexander (1969) The measurement of enteric absorption rate using a double tracer technique. Adv. Biosci., 5:157167.

Siminoski, K., P. Gonnella, J. Bernanke, L. Owen, M. Neutra, and R. A. Murphy (1986) Uptake and transepithelial transport of nerve growth factor in suckling rat ileum. J. Cell Biol., 103:1979-1990.

Sire, M.F., P.Y. Le Bail, U. Georgopoulou, and J.M. Vernier (1988) Transfert transépithélial de protéines au niveau de l'intestin postérieur chez Salmo gairdneri. Biol. Cell, 63: $24 a$.

Suzuki, Y., M. Kobayashi, K. Aida, and I. Hanyu (1988) Transport of physiologically active salmon gonadotropin into the circulation in goldfish, following oral administration of salmon pituitary extract. J. Comp. Physiol. B, 157:753-758.

Wilson, J.M., J.A. Whitney, and M.R. Neutra (1987) Identification of an endosomal antigen specific to absorptive cells of suckling rat ileum. J. Cell Biol., 105:691-703.

Woodward, B., and T. Bergeron (1984) Protein histochemistry of the granule cells in the small intestine of the rainbow trout, Salmo gairdneri Richardson. J. Fish Biol., 24:453458.

Zapata, A. (1979) Ultrastructure of the gut associated lymphoid tissue GALT of Rutilus rutilus. Morf. Normal y Patolog., A3:22-39.

Zohar, Y. (1980) Dorsal aorta catheterization in rainbow trout (Salmo gairdneri). I. Its validity in the study of blood gonadotropin patterns. Reprod. Nutr. Dév., 20:1811-1823.

Zohar, Y. (1982) L'Evolution de la Pulsatilité et des Cycles Nycthéméraux de la Sécrétion Gonadotrope chez la Truite Arc-en-ciel Femelle, en Relation avec le Cycle Sexuel Annuel et par Rapport à l'Activité Stéroïdogène de l'Ovaire. Doc. Sci. Thesis, University of Paris VI (France). 